\title{
Effects of blueberries on migration, invasion, proliferation, the cell cycle and apoptosis in hepatocellular carcinoma cells
}

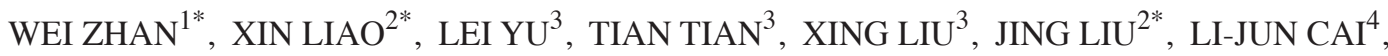 \\ XUAN XIAO ${ }^{3 *}$, RU-JIA XIE ${ }^{3}$ and QIN YANG ${ }^{3}$ \\ Departments of ${ }^{1}$ Anus and Colorectal Surgery, ${ }^{2}$ Radiology, ${ }^{3}$ Pathology and ${ }^{4}$ Neurology, \\ The Affiliated Hospital of Guizhou Medical University, Guiyang, Guizhou 550004, P.R. China
}

Received April 25, 2016; Accepted July 11, 2016

DOI: $10.3892 /$ br.2016.774

\begin{abstract}
The aim of the present study was to investigate the effects of blueberry consumption on the migration, invasion, proliferation, cell cycle and apoptosis in human hepatocellular carcinoma (HCC) cells, in order to provide clinical treatment and prevention strategies for liver cancer using anticancer therapeutic agents. Rabbiteye blueberry was prepared as fresh juice and fed to rats at low, moderate and high dosages $(25,50$ and $100 \%$, respectively) by daily gastric gavage. Seven days later, the rats were sacrificed and the blood serum was obtained for co-culture with HEPG2 cells. The MTT assay was used for detecting cell proliferation, Transwell assay was performed for migration and invasion evaluation, and cell cycle and apoptosis were assessed by flow cytometry. After co-culturing with the blood serum of rats that were fed different dosages of blueberry juice, the inhibition rate of HEPG 2 cells in the three groups was significantly lower than that in the control group at 48 and $72 \mathrm{~h}(\mathrm{P}<0.05)$. The number of migrated and transmembrane HEPG2 cells in the three groups was significantly lower than that in the control group at 48 and $72 \mathrm{~h}(\mathrm{P}<0.05)$. The number of migrated HEPG2 cells in the high dosage group was significantly lower than that in the low dosage group at $48 \mathrm{~h}$, and the numbers of migrated HEPG2 cells in the high and moderate dosage groups were significantly lower than that in the low dosage group at $72 \mathrm{~h}$ $(\mathrm{P}<0.05)$. The number of transmembrane HEPG2 cells in the high dosage group was significantly lower than that in the low dosage group at $48 \mathrm{~h}(\mathrm{P}<0.05)$. The numbers of HEPG2 cells at the $G_{2} / M$ stage in the three groups were significantly
\end{abstract}

Correspondence to: Dr Ru-Jia Xie or Dr Qin Yang, Department of Pathology, The Affiliated Hospital of Guizhou Medical University, 4 Beijing Road, Guiyang, Guizhou 550004, P.R. China

E-mail: xierujia_06@163.com

E-mail: yangqin_06@163.com

${ }^{*}$ Contributed equally

Key words: blueberry, HEPG2, proliferation, invasion, histone acetylation lower than that in the control group, and the number of HEPG2 cells in the high dosage group was significantly lower than that in the low dosage group, at 48 and $72 \mathrm{~h}(\mathrm{P}<0.05)$. The apoptosis rate in the three groups was significantly higher than that in the control group, and the apoptosis rate in the high dosage group was significantly higher than that in the low dosage group at 48 and $72 \mathrm{~h}(\mathrm{P}<0.05)$. Thus, blueberries may facilitate the clinical treatment of $\mathrm{HCC}$, providing a novel therapeutic and prevention strategy for $\mathrm{HCC}$ as an anticancer therapeutic agent.

\section{Introduction}

Liver cancer was the fourth most common cause of mortality worldwide, and China accounted for $\sim 53 \%$ of all liver cancer-associated mortalities (1). The incidence of liver cancer gradually increased in developing (2) and developed (3) countries $(4,5)$. In China, $>90 \%$ of patients with primary liver cancer presented with hepatocellular carcinoma (HCC), which was the second-leading cause of cancer-associated mortality influencing individuals of all ages $(6,7)$. Although treatment and prevention strategies have been clinically developed, the global, overall survival of HCC patients remained particularly poor $(8,9)$. The majority of the poor prognoses were associated with recurrence and metastasis following treatment, including curative resection $(10,11)$. Therefore, the mechanisms of liver cancer recurrence and intervention strategies for liver cancer recurrence and metastasis are required, thus future investigations with larger sample sizes are required.

Blueberry is a member of the Vacciniaceae family (genus, Vaccinium). In the Korean Peninsula and the Northeast of China, blueberries are grown widely and are commonly administered as a traditional Chinese therapeutic agent for treating inflammatory diseases. Blueberry anthocyanins (BAs) were main medicinal active ingredient. Previous studies indicated that BA inhibited tumor growth and induced apoptosis of tumor cells in breast (12), lung (13), and colorectal (14) cancer, amongst others. In addition, BA was reported to be involved in the control of obesity (15) and diabetes mellitus (16), prevention of cardiovascular disease (17), vision augmentation (18) and cerebral function (19).

In the present study, different concentrations of blueberry juice were administered to rats by gastric gavage and, after 
7 days, blood serum was obtained for co-culture with HEPG2 cells. Proliferation, migration, invasion, cell cycle and apoptosis were detected in HEPG2 cells to investigate the effects of blueberry on the proliferation, apoptosis and histone acetylation in HEPG2 cells. The aim of the present study was to establish an anticancer therapeutic agent for the clinical treatment and prevention of liver cancer.

\section{Materials and methods}

Fresh blueberry juice. Rabbiteye blueberries were obtained from the Blueberry Production Field (Ma-Jiang, China) of the Guizhou Academy of Sciences (Guiyang, China) and stored at $-20^{\circ} \mathrm{C}$. The fresh juice was prepared from the crude blueberries by homogenization, and diluted in physiological saline to a final volume of $1 \mathrm{ml}$ [original blueberry juice (100\%) contained $100 \mathrm{~g}$ blueberry, which was further diluted to 25 and $50 \%$ in physiological saline].

Animals. Ethical approval was obtained for the animal experiments from Guizhou Medical University (Guiyang, China), and animal treatment was in accordance with the Guidelines for Animal Care and Use.

Twelve, male, specific pathogen-free (SPF) Wistar rats (weight, $200 \pm 20 \mathrm{~g}$ ) were obtained from the animal center of Guizhou Medical University (Guiyang, China) and maintained in an SPF room, at $25^{\circ} \mathrm{C}$ with a 12 -h of light/dark cycle. The rats had free access to food and water, and were housed separately. The 12 rats were randomly divided into four equal groups as follows: Low-dose group, fed $25 \%$ blueberry juice, which was from the original blueberry juice $(100 \%)$ diluted in saline; moderate-dose group, fed 50\% blueberry juice; high-dose group, fed $100 \%$ blueberry juice; the control group, fed $1 \mathrm{ml}$ physiological saline. Gastric perfusion was performed twice per day at 9:00 a.m. and 9:00 p.m. for 7 days in total. One additional gastric perfusion was performed $2 \mathrm{~h}$ after the final gastric perfusion, in order to prevent vomiting and maintain the blueberry juice concentration. One hour after the repeated gastric perfusion, $10-\mathrm{ml}$ blood samples were collected from the femoral artery of the rats and centrifuged at $1,500 \mathrm{x}$ g for $15 \mathrm{~min}$ at $4^{\circ} \mathrm{C}$. The supernatants obtained from blood samples of rats in the same group were combined. The complement in the blood serum was inactivated at $56^{\circ} \mathrm{C}$ for 30 min using a water bath and a $0.22-\mu \mathrm{m}$ filter (Merck Millipore, Darmstadt, Germany) was used for removing bacteria. The samples of blood serum from rats that were fed different dosages of blueberry juice were stored at $-80^{\circ} \mathrm{C}$. The rats were sacrificed in saturated $\mathrm{CO}_{2}$.

Serum preparation. Serum from the four groups was diluted with 10\% Dulbecco's modified Eagle's medium (DMEM) containing Gibco 10\% fetal bovine serum (FBS; Thermo Fisher Scientific, Inc., Shanghai, China) for co-culture with the HEPG2 cells.

HEPG2 cell culture. HEPG2 cells were obtained from American Type Culture Collection (ATCC) and cultured in DMEM containing $10 \% \mathrm{FBS}$ in $37^{\circ} \mathrm{C}, 5 \% \mathrm{CO}_{2}$ and saturated humidity. When the cell confluence reached $90 \%$, the HEPG2 cells were digested with $0.25 \%(\mathrm{w} / \mathrm{v})$ trypsin containing
$0.53 \mathrm{mM}$ EDTA (Thermo Fisher Scientific, Inc.) and subcultured as described above.

MTT detection of HEPG2 cell proliferation. HEPG2 cells in the logarithmic growth phase were digested with trypsin as a single cell suspension (density, $1 \times 10^{5} / \mathrm{ml}$ ) and resuspended with DMEM containing 10\% FBS. Cell suspension (100 $\mu \mathrm{l})$ was added to each well of a 96-well plate for $24 \mathrm{~h}$ until adhesion. The medium was removed from the 96 -well plate, and serum was added to each well, with 8 parallel wells/group. The cells were then cultured for 48 and $72 \mathrm{~h}$, and the cultured supernatant was collected and stored at $-20^{\circ} \mathrm{C}$. The cells were washed once with $3 \mathrm{ml}$ DMEM and centrifuged to discard the DMEM. Subsequently, $100 \mu 1$ DMEM and $20 \mu 1$ MTT ( $5 \mathrm{mg} / \mathrm{ml}$; Sigma-Aldrich China, Inc., Shanghai, China) were added and incubated at $37^{\circ} \mathrm{C}$ for $4 \mathrm{~h}$. Dimethyl sulphoxide (150 $\mu \mathrm{l}$; Sigma-Aldrich China, Inc.) was added and agitated for $15 \mathrm{sec}$ in the dark for dissolution. An enzyme labeling instrument was used to detect the absorption (A) values at $492 \mathrm{~nm}$. The MTT average value of each group was obtained and the proliferation rate (\%) was calculated as follows:

\section{Control group - treatment group/control group x 100\%}

Transwell assay detection of migration and invasion in HEPG2 cells. For detecting invasion, $4 \mu 1$ Matrigel (BD Biosciences, Franklin Lakes, NJ, USA) was placed in a Transwell chamber (Corning Life Sciences, Shanghai, China) in each well. HEPG2 cells were co-cultured at $37^{\circ} \mathrm{C}$ with DMEM containing 10\% FBS and 10\% serum from the four groups. After 48 and $72 \mathrm{~h}$, the medium was replaced with DMEM without FBS or serum, and the HEPG2 cells were cultured for a further $6 \mathrm{~h}$ at $37^{\circ} \mathrm{C}$. The HEPG2 cells in the logarithmic growth phase were digested with trypsin and the cell density was adjusted to $1 \times 10^{5} / \mathrm{ml}$ by resuspension with DMEM without FBS. The cell suspension $(0.4 \mathrm{ml})$ was added to the upper part of the chamber, and $0.6 \mathrm{ml}$ DMEM containing 20\% FBS (Thermo Fisher Scientific, Inc.) was added to the lower part of the chamber in a 24-well plate, with three parallel holes per group. Subsequently $(24 \mathrm{~h})$, the Matrigel and the non-migrating cells in the chambers were carefully cleaned. Phosphate-buffered saline (PBS; Wuhan Boster Biological Technology, Ltd., Wuhan, China; $1 \mathrm{ml}$ ) was added to the chambers for washing and was discarded. The cells were fixed with $4 \%$ paraformaldehyde (Beijing Solarbio Science \& Technology Co., Ltd., Beijing, China) for $15 \mathrm{~min}$, then stained with $0.1 \%$ crystal violet (Beijing Solarbio Science \& Technology Co., Ltd.) solution at $25^{\circ} \mathrm{C}$ for $20-45 \mathrm{~min}$. The cells were subsequently washed twice with PBS and the stained cells were observed under a microscope (BX51/BX51M; Olympus Corporation, Tokyo, Japan).

For detecting cell migration, the steps were the same as for the detection of invasion, however, Matrigel was not used.

Flow cytometry detection of the HEPG2 cell cycle and apoptosis. Following co-culture with serum from the four groups for 48 and $72 \mathrm{~h}$, the HEPG2 cells were digested with trypsin and centrifuged at $1,000 \mathrm{xg}$ for $5 \mathrm{~min}$ at $25^{\circ} \mathrm{C}$. The supernatant was discarded and the cells were washed twice with PBS. A further centrifugation was performed (at 1,000 $\mathrm{x}$ g for $5 \mathrm{~min}$ 
Table I. A-value and inhibition rate of HEPG2 cells following 48- and 72-h co-culturing with serum from rats fed with different concentrations of blueberry juice. Data are presented as means \pm standard deviations.

\begin{tabular}{lcrrrr}
\hline & & & \multicolumn{3}{c}{ Blueberry treatment group } \\
\cline { 5 - 6 } Variable & $\begin{array}{c}\text { Co-culturing } \\
\text { time }(\mathrm{h})\end{array}$ & Control group & Low-dosage, $25 \%$ & Moderate-dosage, 50\% & High-dosage, $100 \%$ \\
\hline A-value & 48 & $0.58 \pm 0.19$ & $0.46 \pm 0.07^{\mathrm{a}}$ & $0.41 \pm 0.12^{\mathrm{a}}$ & $0.39 \pm 0.05^{\mathrm{a}}$ \\
& 72 & $0.63 \pm 1.77$ & $0.43 \pm 0.10^{\mathrm{a}}$ & $0.40 \pm 0.22^{\mathrm{a}}$ & $0.38 \pm 0.20^{\mathrm{a}}$ \\
Inhibition rate (\%) & 48 & $100.00 \pm 0.00$ & $21.97 \pm 8.54^{\mathrm{a}}$ & $21.33 \pm 10.60^{\mathrm{a}}$ & $20.05 \pm 12.85^{\mathrm{a}}$ \\
& 72 & $100.00 \pm 0.00$ & $20.58 \pm 9.67^{\mathrm{a}}$ & $22.03 \pm 8.14^{\mathrm{a}}$ & $21.90 \pm 10.03^{\mathrm{a}}$ \\
\hline
\end{tabular}

${ }^{a} \mathrm{P}<0.05$ vs. the control group at the corresponding time. A, absorbance.

Table II. Number of migrated or transmembrane HEPG2 cells following 48- and 72-h co-culturing with serum from rats fed with different concentrations of blueberry juice. Data are presented as means \pm standard deviations.

\begin{tabular}{lccccc}
\hline \multirow{2}{*}{$\begin{array}{l}\text { Process } \\
\text { Co-culturing } \\
\text { Mime }(\mathrm{h})\end{array}$} & Control group & Low-dosage, $25 \%$ & Moderate-dosage, 50\% & High-dosage, $100 \%$ \\
\cline { 4 - 6 } & 48 & $65.38 \pm 13.94$ & $50.42 \pm 20.90^{\mathrm{a}}$ & $44.67 \pm 19.58^{\mathrm{a}}$ & $40.03 \pm 21.36^{\mathrm{a}, \mathrm{b}}$ \\
Invasion & 72 & $70.93 \pm 16.03$ & $46.89 \pm 22.64^{\mathrm{a}}$ & $40.91 \pm 26.50^{\mathrm{a}, \mathrm{b}}$ & $38.05 \pm 23.36^{\mathrm{a}, \mathrm{b}}$ \\
& 48 & $110.82 \pm 25.54$ & $91.44 \pm 31.26^{\mathrm{a}}$ & $88.47 \pm 28.95^{\mathrm{a}}$ & $83.39 \pm 34.16^{\mathrm{a}, \mathrm{b}}$ \\
& 72 & $116.85 \pm 30.62$ & $86.59 \pm 36.80^{\mathrm{a}}$ & $82.54 \pm 29.47^{\mathrm{a}}$ & $80.10 \pm 31.34^{\mathrm{a}}$ \\
\hline
\end{tabular}

${ }^{\mathrm{a}} \mathrm{P}<0.05$ vs. the control group; ${ }^{\mathrm{b}} \mathrm{P}<0.05$ vs. the low-dosage group.

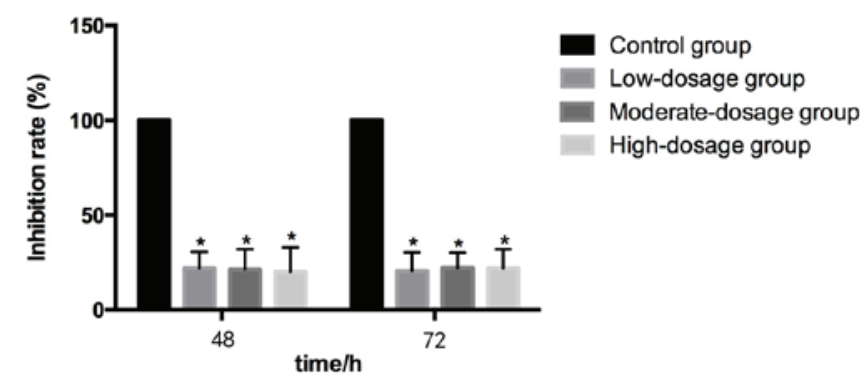

Figure 1. Inhibition rate of HEPG2 cells following 48- and 72-h co-culturing with serum from rats fed with different concentrations of blueberry juice ${ }^{*} \mathrm{P}<0.05$ vs. control group.

at $\left.25^{\circ} \mathrm{C}\right)$ to remove the PBS. Precooled ethanol $(0.6 \mathrm{ml})$ was added and the HEPG2 cells were placed on ice for $30 \mathrm{~min}$. The cells were then centrifuged at $1,000 \mathrm{x}$ g for $5 \mathrm{~min}$ at $25^{\circ} \mathrm{C}$. Subsequently, $0.05 \mathrm{ml}$ RNase A $(10 \mathrm{mg} / \mathrm{ml}$; Sigma-Aldrich China, Inc.) was added and maintained at $25^{\circ} \mathrm{C}$ for $1 \mathrm{~h}$. PBS $(0.15 \mathrm{ml})$ and $0.2 \mathrm{ml}$ propidium iodide (Sigma-Aldrich China, Inc.) were then added to stain the cells. The cell cycle and apoptosis were then analyzed by flow cytometry (BD FACSCalibur; BD Biosciences).

Statistical analysis. Data are presented as the mean \pm standard deviation and were analyzed by SPSS 11.0 software (SPSS, Inc., Chicago, IL, USA). Comparisons between groups were analyzed by Student's t-test and $\mathrm{P}<0.05$ was considered to indicate a statistically significant difference.

\section{Results}

HEPG2 proliferation. Table I and Fig. 1 demonstrate the A-value and inhibition rate of HEPG2 cells after co-culturing with the serums from the different treatment groups for 48 and $72 \mathrm{~h}$. Compared with the control group at $48 \mathrm{~h}$, the inhibition rates of HEPG2 cells in the low- $(21.97 \pm 8.54 \%)$, moderate- $(20.33 \pm 10.60 \%)$ and high- $(20.05 \pm 12.85 \%)$ dosage groups were significantly lower $(\mathrm{P}<0.05)$. However, there were no significant differences in HEPG2 cell proliferation between the three blueberry treatment groups at $48 \mathrm{~h}$. Furthermore, the inhibition rate decreased as the concentration of blueberry juice intake increased.

Compared with the control group at $72 \mathrm{~h}$, the inhibition rates of HEPG2 cells in the low- $(20.58 \pm 9.67 \%)$, moderate$(21.03 \pm 8.14 \%)$ and high- $(21.90 \pm 10.3 \%)$ dosage groups were significantly lower $(\mathrm{P}<0.05)$. However, there were no significant differences in HEPG2 cell proliferation between the three blueberry treatment groups at $72 \mathrm{~h}$. Furthermore, the inhibition rate decreased as the concentration of blueberry juice intake increased.

In addition, the inhibition rates between the different groups at 48 and $72 \mathrm{~h}$ were not statistically different.

Migration and invasion in HEPG2 cells. Table II demonstrates the number of migrated or transmembrane HEPG2 cells following co-culturing with serums for 48 and $72 \mathrm{~h}$, which were obtained from rats that were fed different concentrations of blueberry juice. 
Table III. HEPG2 cell cycle analysis following 48- and 72-h co-culturing with serum from rats fed with different concentrations of blueberry juice. Data are presented as means \pm standard deviations.

\begin{tabular}{|c|c|c|c|c|c|}
\hline \multirow[b]{2}{*}{ Stage } & \multirow{2}{*}{$\begin{array}{l}\text { Co-culturing } \\
\text { time (h) }\end{array}$} & \multirow[b]{2}{*}{ Control group } & \multicolumn{3}{|c|}{ Blueberry treatment group } \\
\hline & & & Low-dosage, $25 \%$ & Moderate-dosage, $50 \%$ & High-dosage, $100 \%$ \\
\hline \multirow[t]{2}{*}{$\mathrm{G}_{0} / \mathrm{G}_{1}(\%)$} & 48 & $65.58 \pm 2.68$ & $61.40 \pm 2.80$ & $73.02 \pm 1.48$ & $76.21 \pm 2.53$ \\
\hline & 72 & $59.37 \pm 3.90$ & $68.14 \pm 2.30$ & $74.95 \pm 3.13$ & $69.62 \pm 2.98$ \\
\hline \multirow[t]{2}{*}{ S (\%) } & 48 & $20.96 \pm 2.05$ & $31.09 \pm 2.46$ & $23.17 \pm 1.55$ & $22.89 \pm 2.60$ \\
\hline & 72 & $25.24 \pm 3.07$ & $18.79 \pm 2.33$ & $17.20 \pm 1.98$ & $23.95 \pm 2.65$ \\
\hline \multirow[t]{2}{*}{$\mathrm{G}_{2} / \mathrm{M}(\%)$} & 48 & $13.96 \pm 2.73$ & $7.53 \pm 1.12^{\mathrm{a}}$ & $4.60 \pm 1.08^{\mathrm{a}}$ & $1.52 \pm 0.97^{\mathrm{a}, \mathrm{b}}$ \\
\hline & 72 & $17.53 \pm 3.54$ & $13.82 \pm 2.04^{\mathrm{a}}$ & $7.48 \pm 1.40^{\mathrm{a}}$ & $6.30 \pm 1.52^{\mathrm{a}, \mathrm{b}}$ \\
\hline
\end{tabular}

${ }^{\mathrm{a}} \mathrm{P}<0.05$ vs. the control group; ${ }^{\mathrm{b}} \mathrm{P}<0.05$ vs. the low-dosage group.

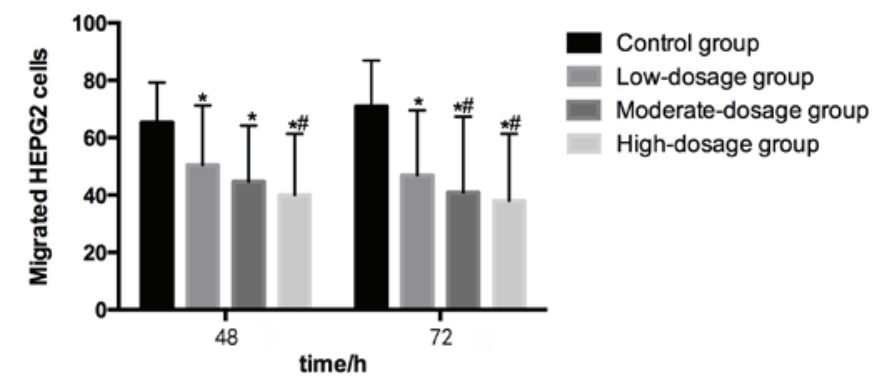

Figure 2. Number of migrated HEPG2 cells following 48- and 72-h coculturing with serum from rats fed with different concentrations of blueberry juice. ${ }^{*} \mathrm{P}<0.05$ vs. the control group; ${ }^{\#} \mathrm{P}<0.05$ vs. the low-dosage group.

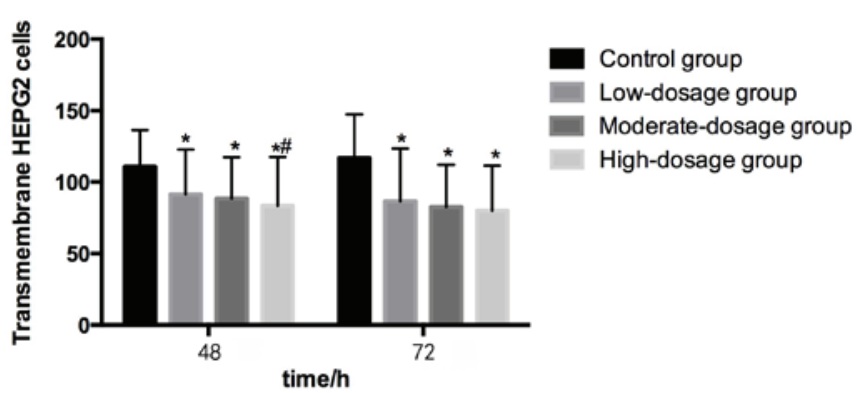

Figure 3. Number of transmembrane HEPG2 cells following 48- and 72-h co-culturing with serum from rats fed with different concentrations of blueberry juice. ${ }^{*} \mathrm{P}<0.05$ vs. the control group; ${ }^{*} \mathrm{P}<0.05$ vs. the low-dosage group.

Compared with the control group $(65.38 \pm 13.94)$ at $48 \mathrm{~h}$, the numbers of migrated HEPG2 cells in the low- $(50.42 \pm 20.90)$, moderate- $(44.67 \pm 19.58)$ and high- $(40.03 \pm 21.36)$ dosage groups were significantly lower $(\mathrm{P}<0.05)$. The number of metastatic HEPG 2 cells in the high-dosage group was significantly lower than that in the low-dosage group $(\mathrm{P}<0.05)$. Furthermore, the number of metastatic HEPG2 cells decreased as the concentration of blueberry juice intake increased (Table II and Fig. 2).

Compared with the control group $(70.93 \pm 16.03)$ at $72 \mathrm{~h}$, the numbers of migrated HEPG2 cells in the low- (46.89 \pm 22.64$)$, moderate- $(40.91 \pm 26.50)$ and high- $(38.05 \pm 23.36)$ dosage groups were significantly lower $(\mathrm{P}<0.05)$. The numbers of metastatic HEPG2 cells in the moderate- and high-dosage

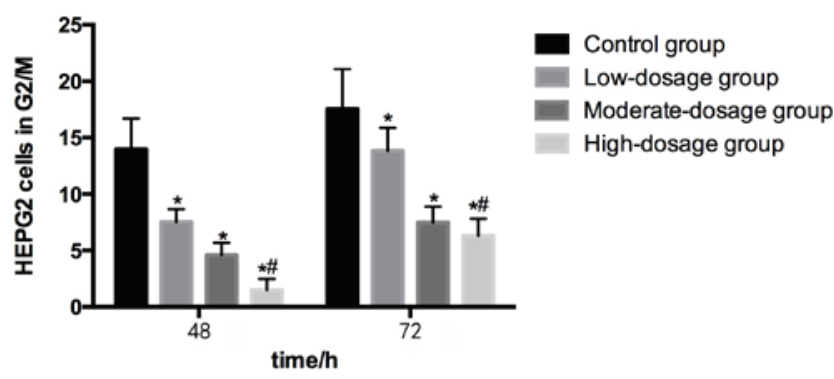

Figure 4. Number of HEPG2 cells at the $\mathrm{G}_{2} / \mathrm{M}$ stage following 48- and 72-h co-culturing with serum from rats fed with different concentrations of blueberry juice. ${ }^{*} \mathrm{P}<0.05$ vs. the control group; ${ }^{\text {}} \mathrm{P}<0.05$ vs. the low-dosage group.

groups were significantly lower than in the control group $(\mathrm{P}<0.05)$. The number of metastatic HEPG2 cells decreased as the concentration of blueberry juice intake increased (Table II and Fig. 2).

Compared with the control group $(110.82 \pm 25.54)$ at $48 \mathrm{~h}$, the numbers of transmembrane HEPG2 cells in the low- $(91.44 \pm 31.26)$, moderate- $(88.47 \pm 28.95)$ and high- $(83.39 \pm 34.16)$ dosage groups were significantly lower $(\mathrm{P}<0.05)$. The number of transmembrane HEPG2 cells in the high-dosage group was significantly lower than in the control group $(\mathrm{P}<0.05)$. The transmembrane HEPG2 cell number tended to decrease as the concentration of blueberry juice intake increased (Table II and Fig. 3).

Compared with the control group $(116.85 \pm 30.62)$ at $72 \mathrm{~h}$, the numbers of transmembrane HEPG2 cells in the low- $(86.59 \pm 36.80)$, moderate- $(82.54 \pm 29.47)$ and high- $(80.10 \pm 31.34)$ dosage groups were significantly lower $(\mathrm{P}<0.05)$. However, no significant differences were identified in transmembrane HEPG2 cell numbers among the three groups that were administered blueberry juice. The transmembrane HEPG2 cell number tended to decrease as the concentration of blueberry juice intake increased (Table II and Fig. 3).

Flow cytometric detection of the HEPG2 cell cycle and apoptosis. Table III and Fig. 4 demonstrate the HEPG2 cell cycle (in $\mathrm{G}_{2} / \mathrm{M}$ ) subsequent to co-culturing for 48 and $72 \mathrm{~h}$ with serum from rats that were administered different concentrations of blueberry juice. 
Table IV. Apoptosis rate of HEPG2 cell following 48- and 72-h co-culturing with serum from rats fed with different concentrations of blueberry juice. Data are presented as means \pm standard deviations.

Blueberry treatment group

\begin{tabular}{lcccc}
\multirow{2}{*}{$\begin{array}{l}\text { Co-culturing } \\
\text { time }(\mathrm{h})\end{array}$} & Control group & Low-dosage, 25\% & Moderate-dosage, 50\% & High-dosage, 100\% \\
\cline { 3 - 5 } & $4.25 \pm 0.78$ & $7.66 \pm 1.14^{\mathrm{a}}$ & $10.96 \pm 1.38^{\mathrm{a}}$ & $30.42 \pm 3.95^{\mathrm{a}, \mathrm{b}}$ \\
48 & $5.32 \pm 1.79$ & $13.57 \pm 1.97^{\mathrm{a}}$ & $20.42 \pm 2.06^{\mathrm{a}, \mathrm{b}}$ & $67.64 \pm 1.85^{\mathrm{a}, \mathrm{b}}$
\end{tabular}

${ }^{\mathrm{a}} \mathrm{P}<0.05$ vs. the control group; ${ }^{\mathrm{b}} \mathrm{P}<0.05$ vs. the low-dosage group.

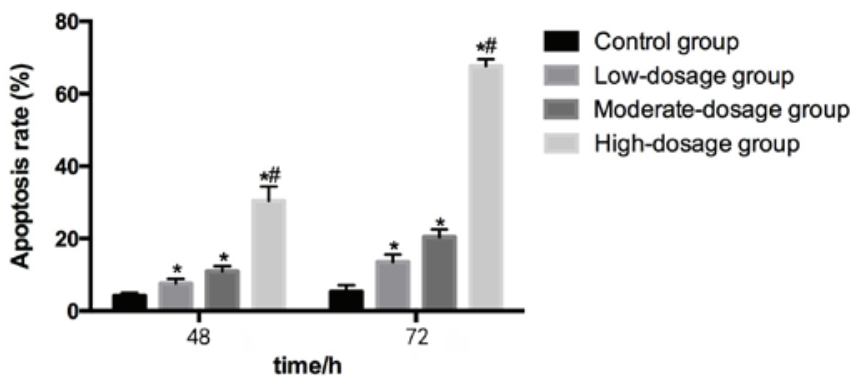

Figure 5. Apoptosis rate of HEPGH2 cells following 48- and 72-h co-culturing with serum from rats fed with different concentrations of blueberry juice. ${ }^{*} \mathrm{P}<0.05$ vs. the control group; ${ }^{\#} \mathrm{P}<0.05$ vs. the low-dosage group.

Compared with the control group $(13.96 \pm 2.73 \%)$ at $48 \mathrm{~h}$, the numbers of HEPG2 cells at the $\mathrm{G}_{2} / \mathrm{M}$ stage in the low$(7.53 \pm 1.12 \%)$, moderate- $(4.60 \pm 1.08) \%$ and high- $(1.52 \pm 0.97 \%)$ dosage groups were significantly lower $(\mathrm{P}<0.05)$. The number of HEPG2 cells at the $\mathrm{G}_{2} / \mathrm{M}$ stage in the high-dosage group was significantly lower than in the low-dosage group $(\mathrm{P}<0.05)$. The number of HEPG2 cells at the $\mathrm{G}_{2} / \mathrm{M}$ stage decreased as the concentration of blueberry juice intake increased.

Compared with the control group $(17.53 \pm 3.54 \%)$ at $72 \mathrm{~h}$, the numbers of HEPG 2 cells at the $\mathrm{G}_{2} / \mathrm{M}$ stage in the low$(13.82 \pm 2.04 \%)$, moderate- $(7.48 \pm 1.40 \%)$ and high- $(6.30 \pm 1.52 \%)$ dosage groups were significantly lower $(\mathrm{P}<0.05)$. The number of HEPG2 cells at the $\mathrm{G}_{2} / \mathrm{M}$ stage in the high-dosage group was significantly lower than in the low-dosage group $(\mathrm{P}<0.05)$. The number of HEPG2 cells at the $\mathrm{G}_{2} / \mathrm{M}$ stage decreased as the concentration of blueberry juice intake increased.

Table IV and Fig. 5 demonstrate the apoptosis rate of HEPG 2 cells subsequent to co-culturing for 48 and $72 \mathrm{~h}$ with serum from rats that were administered different concentrations of blueberry juice.

Compared with the control group $(4.25 \pm 0.78 \%)$ at $48 \mathrm{~h}$, the apoptosis rates in the low- $(7.66 \pm 1.14 \%)$, moderate$(10.96 \pm 1.38 \%)$ and high- $(30.42 \pm 3.95 \%)$ dosage groups were significantly higher $(\mathrm{P}<0.05)$. The apoptosis rate in the high-dosage group was significantly greater than in the low-dosage group. The apoptosis rate increased as the concentration of blueberry juice intake increased.

Compared with the control group $(5.32 \pm 1.79 \%)$ at $72 \mathrm{~h}$, the apoptosis rates in the low- $(13.57 \pm 1.97 \%)$, moderate$(20.42 \pm 2.06 \%)$ and high- $(67.64 \pm 1.85 \%)$ dosage groups were significantly higher $(\mathrm{P}<0.05)$. The apoptosis rate in the high-dosage group was significantly higher than in the low-dosage group. The apoptosis rate increased as the concentration of blueberry juice intake increased.

\section{Discussion}

Blueberries contain numerous components, some of which have been reported to facilitate with the prevention of different diseases. For example, anthocyanin is a main component of blueberry, and the high anthocyanin content of blueberries was found to be chemopreventive and exerted therapeutic effects against breast cancer (19). Pterostilbene, primarily found in blueberries, is an antioxidant that acts as an effective anticancer agent in various common malignancies, including breast and colon cancer (20). In addition, ellagic acid has been associated with the prevention of oxidative DNA damage and modulation of DNA repair gene expression (21). These components interact and influence biological processes in the human body, resulting in the potentially protective and preventive actions of blueberries.

In the present study, the blueberry components were not detected and the important components were not extracted from the fresh blueberries. However, fresh blueberry juice was fed to the rats and the serum was collected. The serum from the blueberry-fed rats was used for co-culturing with HEPG2 cells, and the proliferation, invasion, migration, cell cycle and apoptosis in HEPG2 cells was detected following culture with serums taken from rats fed with different concentrations of blueberry juice. The results indicated that the blueberry juice exerted significant antitumor and therapeutic effects on HEPG2 cells. The different concentrations of blueberry juice and varying treatment times resulted in distinct influences on the invasion, migration, proliferation, cell cycle and apoptosis in the HEPG2 cells.

Following co-culture with serum obtained from blueberry-fed rats, the inhibition rates of HEPG2 cells in the low-, moderate- and high-dosage groups were significantly lower than in the control group, at 48 and $72 \mathrm{~h}(\mathrm{P}<0.05)$. The migrated and transmembrane HEPG2 cells in the three treatment groups were significantly lower than in the control group, at 48 and $72 \mathrm{~h}(\mathrm{P}<0.05)$. The number of migrated HEPG2 cells in the high-dosage group was lower than in the low-dosage group at $48 \mathrm{~h}$, and that of the high- and moderate-dosage groups were significantly lower than in the low-dosage groups at $72 \mathrm{~h}(\mathrm{P}<0.05)$. The number of transmembrane HEPG2 cells in the high-dosage group was significantly lower than in the low-dosage group at $48 \mathrm{~h}(\mathrm{P}<0.05)$. Furthermore, the numbers 
of HEPG2 cells at the $\mathrm{G}_{2} / \mathrm{M}$ stage in the treatment groups were significantly lower than in the control group, and the number of HEPG 2 cells at the $\mathrm{G}_{2} / \mathrm{M}$ stage in the high-dosage group was significantly lower than in the low-dosage group at 48 and $72 \mathrm{~h}(\mathrm{P}<0.05)$. The apoptosis rates of the treatment groups were significantly higher than those in the control group, and the apoptosis rate in the high-dosage group was significantly higher than that in the low-dosage group at 48 and $72 \mathrm{~h}(\mathrm{P}<0.05)$.

In the study by Faria et al (12) the anthocyanins and anthocyanin-pyruvic acid adducts were extracted from blueberries, and demonstrated anticancer properties in breast cancer cell lines. Similar results were observed by Li et al (22) and $\mathrm{Lu}$ et al (23). The majority of previous studies were based on the extraction of key components of blueberries; however, there are fewer studies with the comprehensive detection of their (blueberry components or the original blueberry juice) influence on HEPG2 cells. There were, however, certain limitations of the present study as follows: No specific components were extracted from the blueberries. The blueberry juice was diluted to different concentrations to feed the rats; however, it was the serum of the rats, and not the blueberry juice directly, that was co-cultured with the HEPG2 cells. Furthermore, the treatment times were short and, therefore, did not provide data on the long-term therapeutic and protective effects of blueberries on HCC or HEPG2 cells. Thus, the detailed effects of blueberry on $\mathrm{HCC}$ or other types of cancer require further clinical investigation.

In conclusion, the present study evaluated common processes that are influenced by blueberry components, including migration, invasion, proliferation, the cell cycle and apoptosis. These influences indicate the protective and therapeutic effects of blueberries on HCC, and their antitumor effects on HEPG2 cells.

\section{References}

1. Pisani P, Parkin DM, Bray F and Ferlay J: Estimates of the worldwide mortality from 25 cancers in 1990. Int J Cancer 83: $18-29,1999$.

2. Tang ZY: Hepatocellular carcinoma - cause, treatment and metastasis. World J Gastroenterol 7: 445-454, 2001.

3. El-Serag HB and Mason AC: Rising incidence of hepatocellular carcinoma in the United States. N Engl J Med 340: 745-750, 1999.

4. Taylor-Robinson SD, Foster GR, Arora S, Hargreaves S and Thomas HC: Increase in primary liver cancer in the UK, 1979-94. Lancet 350: 1142-1143, 1997.

5. Tabor E: Hepatocellular carcinoma: global epidemiology. Dig Liver Dis 33: 115-117, 2001.

6. Zhang S, Li L and Lu F: Mortality of primary liver cancer in China from 1990 through 1992. Zhonghua Zhong Liu Za Zhi 21: 245-249, 1999 (In Chinese).
7. Chen JG and Zhang SW: Liver cancer epidemic in China: Past, present and future. Semin Cancer Biol 21: 59-69, 2011.

8. Tang ZY, Yu YQ, Zhou XD, Ma ZC and Wu ZQ: Progress and prospects in hepatocellular carcinoma surgery. Ann Chir 52: 558-563, 1998.

9. Jiang E, Shangguan AJ, Chen S, Tang L, Zhao S and Yu Z: The progress and prospects of routine prophylactic antiviral treatment in hepatitis B-related hepatocellular carcinoma. Cancer Lett 379: 262-267, 2016.

10. Samiei M and Waghorne CG: Clonal selection within metastatic SP1 mouse mammary tumors is independent of metastatic potential. Int J Cancer 47: 771-775, 1991.

11. Tang Z, Zhou X, Lin Z, Yang B, Ma Z, Ye S, Wu Z, Fan J, Liu Y, Liu K, et al: Surgical treatment of hepatocellular carcinoma and related basic research with special reference to recurrence and metastasis. Chin Med J (Engl) 112: 887-891, 1999.

12. Faria A, Pestana D, Teixeira D, de Freitas V, Mateus N and Calhau C: Blueberry anthocyanins and pyruvic acid adducts: anticancer properties in breast cancer cell lines. Phytother Res 24: 1862-1869, 2010.

13. Chen PN, Chu SC, Chiou HL, Kuo WH, Chiang CL and Hsieh YS: Mulberry anthocyanins, cyanidin 3-rutinoside and cyanidin 3-glucoside, exhibited an inhibitory effect on the migration and invasion of a human lung cancer cell line. Cancer Lett 235: 248-259, 2006.

14. Kang SY, Seeram NP, Nair MG and Bourquin LD: Tart cherry anthocyanins inhibit tumor development in Apc(Min) mice and reduce proliferation of human colon cancer cells. Cancer Lett 194: 13-19, 2003.

15. Wu T, Qi X, Liu Y, Guo J, Zhu R, Chen W, Zheng X and Yu T: Dietary supplementation with purified mulberry (Morus australis Poir) anthocyanins suppresses body weight gain in high-fat diet fed C57BL/6 mice. Food Chem 141: 482-487, 2013.

16. Ghosh D and Konishi T: Anthocyanins and anthocyanin-rich extracts: role in diabetes and eye function. Asia Pac J Clin Nutr 16: 200-208, 2007.

17. Toufektsian MC, de Lorgeril M, Nagy N, Salen P, Donati MB, Giordano L, Mock HP, Peterek S, Matros A, Petroni K, et al: Chronic dietary intake of plant-derived anthocyanins protects the rat heart against ischemia-reperfusion injury. J Nutr 138: 747-752, 2008

18. Tsuda T: Dietary anthocyanin-rich plants: biochemical basis and recent progress in health benefits studies. Mol Nutr Food Res 56: 159-170, 2012.

19. Jeyabalan J, Aqil F, Munagala R and Gupta R: Chemopreventive and therapeutic activity of high anthocyanin-content blueberry against estrogen-mediated breast cancer. Cancer Res 73: 3705,2013

20. McCormack D and McFadden D: Pterostilbene and cancer: current review. J Surg Res 173: e53-e61, 2012.

21. Aiyer HS, Vadhanam MV, Stoyanova R, Caprio GD, Clapper ML and Gupta RC: Dietary berries and ellagic acid prevent oxidative DNA damage and modulate expression of DNA repair genes. Int J Mol Sci 9: 327-341, 2008.

22. Li YW, Wang D, Li XG and Jin Y: Anthocyanins extracted from chinese blueberry and its anticancer effects on HepG2 cells. Adv Mat Res 887-888: 592-595, 2014

23. Lu YC, Liu YX, Wu W, Zhou F, Ji BP and Su CY: Preventive effect of blueberry polyphenols on oleic acid-induced fat accumulation in HepG2 cells. Food Science 32: 308-312, 2011 (In Chinese). 